\title{
OBITUARY
}

\section{FRANK HATTON BRIGHTMAN}

(1921-1996)

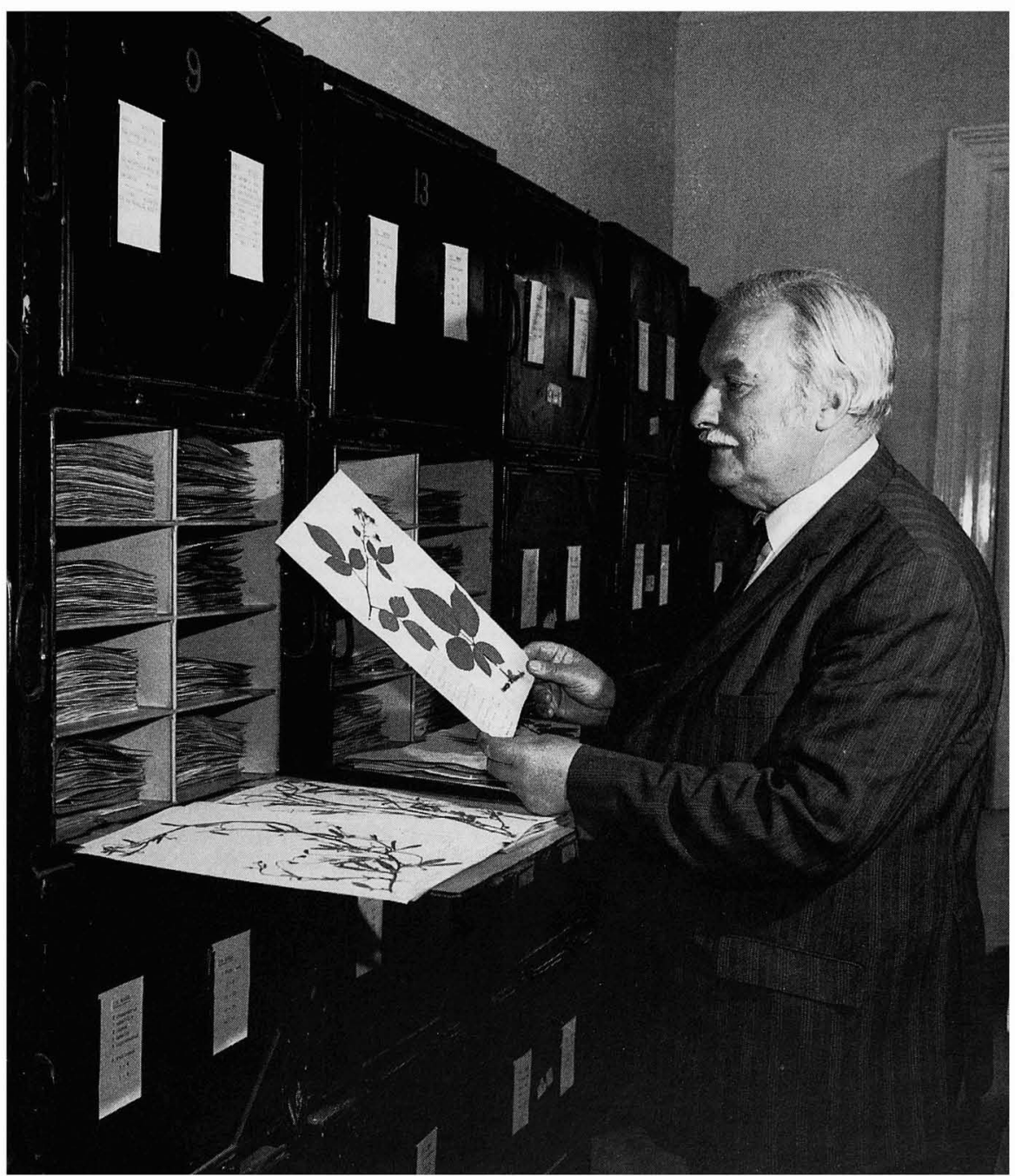

Frank Brightman, gentleman and scholar, was a commanding figure who impressed everyone who came into contact with him and for those of us who were privileged to know him in his personal as well as his professional capacity, life will never be quite the same. 
Born at Leyton, Essex, on 15 May 1921, Frank was educated at the County High School for Boys, Leyton. In October 1939 he entered University College, London (then operating from University College North Wales, Bangor), from which he graduated with an honours degree in botany in June 1942. In September of that year he was called up and after a short time working on radar development at the Army Radio School at Petersham, he was commissioned in REME, but had to relinquish this for medical reasons, retiring with the honorary rank of second lieutenant. After convalescing from an operation to remove a kidney, he was appointed as science master at the South East London Emergency Secondary School. When war ended, the school was disbanded and Frank moved to the County Grammar School for Boys, Beckenham and Penge, where he was to spend the next 25 years, first as Senior Biology Master and later as Head of Science. The number of state scholarships and university entries gained by his pupils testify to Frank's ability to communicate his own enthusiasm for biology and the thoroughness of his teaching.

In 1970 Frank was appointed Head of the newly formed Education Section of the British Museum (Natural History), where he remained until his retirement in 1981. However, he had no intention of retiring to a life of leisure and devoted much of his time to the regeneration of the South London Botanical Institute, and more particularly its garden: the joint efforts of Frank and his wife Janice resulted in an invitation to join the National Gardens Scheme. The Institute's Council elected him as a Fellow and for many years he held the honorary title of Director in recognition of his services in promoting its education and scientific role.

Frank was actively involved in many other organizations concerned with plants, and more particularly their conservation. He joined the Botanical Society of the British Isles in 1957, serving on its Conservation Committee from 1965 and on its Council for 1988-1991. He was deeply involved in the activities of the Kent Field Club from 1957, editing its journal from 1974 to 1988 and becoming its President from 1992 to 1994; his special interest in the lower plants led him to initiate his innovative annual 'wall tours' under the aegis of the Club, which he conducted for over 20 years, introducing many to the study of bryophytes and lichens. Frank was also a member of the British Bryological Society, a founder member of the Kent Trust for Nature Conservation, and an honorary warden of Downe Bank, the internationally famous orchid site first studied by Charles Darwin. In addition, Frank was an active and highly regarded Fellow of the Linnean Society, serving on its Council from 1988 to 1991, and on several of its committees. In 1995, the Society honoured him with the title 'Fellow Honoris Causa' for his services to botany. From 1977 to 1990 he edited Natural History Book Reviews, a journal in whose content he took particular pride and pleasure, in spite of problems over its printing, publishing, and distribution that contributed to its untimely and regretted demise.

It is for his services to British lichenology that Frank Brightman will be most remembered. He was a founder member of the British Lichen Society in 1958 and remained one of its most loyal and deeply committed members. As well as being its President from 1978 to 1980, he was constantly called upon 
throughout his long association with our Society to serve on Council, chair committees and meetings, and to edit and contribute to various of its publications. He ran the Lichen Study Group from 1958 until 1962, was Curator from 1964 until 1970, and acted as referee for the naming of specimens from 1966 until 1990. He stood in as Bulletin Editor during 1987 and was Conservation Chairman from 1962 to 1980 and from 1987 until 1989. In recognition of his many services to the Society and British lichenology, he was made an Honorary Member in 1988.

For many like myself, our enthusiasm for lichens was first fired by Frank's stimulating paper 'Neglected plants-lichens', which appeared in New Biology in 1959 , at a time when no similar popular introduction was available. We accepted the challenge of his paper's title, and responded to the clarion call of its concluding paragraph: 'These neglected plants, whose fascination increases the better one becomes acquainted with them, can be commended without reservation to botanists in search of a subject, amateur and professional alike'. For many others, both amateur and professional, their introduction to lichenology can be attributed to Frank's enthusiasm and initiatives, as demonstrated by the wall tours referred to above, the successful field courses he ran for many years at Kindrogan Field Centre, and his superbly organized BLS field meetings, on which he always made a particular point of helping and encouraging novices. Furthermore, his successful collaboration with Barbara Nicholson on the Oxford Book of Flowerless Plants, published in 1966, did much to promote popular interest in the subject.

Frank's lichenological publications formed only a small part of his extensive published output: as well as those listed in the appended bibliography, he was a regular contributor to the Society's Bulletin. He compiled the column 'New, rare and interesting British lichen records' for the Bulletin from 1988 until 1993. Many readers particularly enjoyed the jeux d'esprit which he contributed under his pseudonym 'Cudbear', whose identity was a well-kept secret for many years.

Notwithstanding his deep commitment to those scientific interests highlighted above, Frank still somehow found time to pursue a wide variety of literary and artistic interests. These included the cinema, more particularly films starring Humphrey Bogart. The writings of Raymond Chandler, Rudyard Kipling, R. S. Surtees, H. G. Wells, and Robert Graves especially appealed to him - his prodigious memory enabling him to quote extensively from all of these and other well-read favourites! He was, for example, an active member of the Kipling Society and a founder member of the R. S. Surtees Society, the latter reflecting his interest in 19th century sporting literature, although he never actually hunted or indeed rode a horse. His interests were often unexpected-for instance, he co-edited The Book of Secrets of Albertus Magnus (1973). His general knowledge was remarkable, often encyclopaedic, in its scope, backed up by a photographic memory, even of subjects in which he gave the impression he had little interest. Frank's life was devoted to education in its widest sense.

Besides his scientific and literary pursuits, Frank was active in the Old Students' Association of University College, London, which made him its President in 1992, sadly at a time that coincided with the onset of the serious 
illnesses that overshadowed the last four years of his life. Nevertheless, he doggedly persevered with his duties to this society and others, even when confined to the wheelchair that latterly so grievously circumscribed his movements. He was, as he had always been, warmly welcomed at those meetings which, thanks to Janice's devoted help, he was able to attend, but for those like myself who remembered the commanding figure of former days, it was heartbreaking to see his physical decline, although we were still able to appreciate glimpses of his wit, genius, and very individual sense of humour. Four years of suffering finally came to an end on 20 June 1996.

On a personal note, I have lost one of my greatest friends: for 35 years he was not only my mentor but my adopted 'elder brother'. Throughout the whole of our long association, not a week went by without a communication, usually a letter, from him, as testified to by the voluminous correspondence file I have amassed, kept not just for its personal content but as a mine of invaluable information. Nor was I the only one to benefit from his wisdom: through his prompt and full attention to correspondence Frank built up an international following.

Frank established standards that are difficult to emulate. The world of lichenology will never be quite the same again-we can only be grateful that we were privileged to know a truly great man. The Society extends its sincerest sympathies to his widow, Janice, to the son and daughter of his first marriage, and to the many who have suffered the loss of a dear friend.

\section{Bibliography}

Frank Brightman's published output was considerable, both on scientific and literary subjects, but the following list refers specifically to those articles with a significant lichenological component.

Brightman, F. H. (1959) Neglected plants-lichens. New Biology 29: 75-94.

Brightman, F. H. (1959) Some factors influencing lichen growth in towns. Lichenologist 1: 104-108.

Brightman, F. H. (1959) Lichen weekend at Flatford. Lichenologist 1: 119.

Brightman, F. H. (1960) Antibiotics from lichens. Biology \& Human Affairs 26: 1-5.

Brightman, F. H. (1960) Lichen meeting at Flatford. Lichenologist 1: 203-206.

Brightman, F. H. (1962) Field meeting at Arnside. Lichenologist 2: 97-100.

Brightman, F. H. (1964) Cyphelium notarisii in Britain. Lichenologist 2: 283-284.

Brightman, F. H. (1964) The distribution of the lichen Lecanora conizaeoides Cromb. in north Ireland. Irish Naturalists' fournal 14: 258-262.

Brightman, F. H. (1965) Lichens. Bulletin of the British Mycological Society [old series] 24: 11-13.

Brightman, F. H. (1965) Insect on lichens. Lichenologist 3: 154.

Brightman, F. H. (1965) The lichens of Cambridge walls. Nature in Cambridgeshire 8: 45-50.

Brightman, F. H. (1965) Field meeting at Folkestone. Lichenologist 3: 173-174.

Side, A. G. \& Brightman, F. H. (1965) Notes on the bryophytes and lichens of Ruxley Gravel Pit. Transactions of the Kent Field Club. 3: 69-70.

Brightman, F. H. (1965) Some patterns of distribution of lichens in southern England. South-Eastern Naturalist $\mathcal{E}$ Antiquary 69: 10-17.

Nicholson, B. E. \& Brightman, F. H. (1966) The Oxford Book of Flowerless Plants. London: Oxford University Press.

Brightman, F. H., James, P. W. \& Rose, F. (1973) Distribution maps of lichens in Britain. Map 6. Parmelia acetabulum (Neck.) Duby. Lichenologist 5: 476-477.

Brightman, F. H. \& Seaward, M. R. D. (1977) Lichens of man-made substrates. In: Lichen Ecology (M. R. D. Seaward ed.): 253-293. London: Academic Press. 
Brightman, F. H. \& Lambley, P. W. (1978) Field meeting at Cambridge. Lichenologist 10: 105-109.

Brightman, F. H. (1982) Barbara Nicholson's Plants of the British Isles. London: Collins.

Brightman, F. H. (1982) Field meeting in Tenerife, Canary Islands: introduction. Lichenologist 14: $57-61$.

Seaward, M. R. D. \& Brightman, F. H. (1983) Notes on the bryophytes and lichens of Ruxley Gravel Pit. Transactions of the Kent Field Club 9: 101-102.

Brightman, F. H. (1984) Vegetable dyeing for amateurs: a selected bibliography. Natural History Book Reviews 7: 117-121.

Brightman, F. H. \& Seaward, M. R. D. (1989) Obituary: Arthur Wade 1895-1989. Lichenologist 21: 379-381.

In addition to the above list, Frank Brightman co-authored the sections dealing with Gomphillus, Haematomma, Icmadophila and Ophioparma in The Lichen Flora of Great Britain and Ireland (1992), and was a regular contributor to the Bulletin of the British Lichen Society, many articles appearing under the pseudonym "Cudbear". He also contributed numerous lichen notes and field meeting reports to the Bulletin of the Kent Field Club from 1960 to 1976 (5: 26-28; 6: 7-8, 33-44; 7: 8, 19-20, 44; 8: 6-7; 9: 7, 16, 37; 10: 7, 10; 11: 8, 13-14; 12: 7-8, 9-10; 13: 7-8; 14: 6-7, 24; 15: $7-9,19 ; 16: 7-8,20 ; 19: 12-13 ; 20: 5-6 ; 21: 7)$.

M. R. D. Seaward 